\title{
DETERMINAN KINERJA KEUANGAN PERUSAHAAN PADA PERUSAHAAN MANUFAKTUR YANG TERDAFTAR DI BURSA EFEK INDONESIA
}

\author{
DETERMINANTS OF COMPANY FINANCIAL PERFORMANCE IN \\ MANUFACTURING COMPANIES LISTED IN INDONESIA STOCK EXCHANGE
}

\author{
Jusmarni \\ Sekolah Tinggi Ilmu Ekonomi Persada Bunda \\ jusmarni@stiepersadabunda.ac.id
}

\begin{abstract}
Stocks are currently a popular investment product among investors. Stocks that are of interest to investors are stocks that have a high selling value because the stock price is a very important factor to pay attention to and indicators are used to measure the welfare of shareholders. The higher the share price, the higher the value of the company and vice versa. However, investing in stocks in the capital market is also filled with an element of uncertainty or risk, this is because investors do not know with certainty the results they will get from their investments. Company specific financial information is one of the important internal company factors that can influence investors to invest. The research aims to analyse the effect of Capital Structure, liquidity, and profitability on stock price. Samples used in this study are food and beverage companies listed in the Indonesian Stock Exchange during 2016-2018 periods. Multiple linear regression method used to anlyse the effect of DER,CAR, and NPM on Stock Price. The results showed that DER and CAR have not significant effect on Stock Price. NPM have a significant effect on Stock Price.
\end{abstract}

Keywords: Capital Structure, liquidity, Profitability, Stock Price

\begin{abstract}
ABSTRAK
Saham saat ini menjadi produk investasi populer dikalangan investor. Saham yang diminati investor adalah saham yang mempunyaai nilai jual tinggi karena harga saham merupakan faktor yang sangat penting untuk diperhatikan dan indikator digunakan untuk mengukur kesejahteraan pemegang saham. Semakin tinggi harga saham, maka semakin tinggi nilai perusahaan tersebut dan begitu pula sebaliknya. Namun berinvestasi saham di pasar modal juga dipenuhi dengan unsur ketidakpastian atau risiko, ini dikarena investor tidak tahu dengan pasti hasil yang akan diperolehnya dari investasi yang dilakukannya. Informasi spesifik keuangan perusahaan merupakan salah satu faktor intern perusahaan yang penting yang dapat mempengaruhi investor untuk berinvestasi. Penelitian ini bertujuan untuk menganalisis pengaruh Struktur Modal, likuiditas, dan profitabilitas terhadap harga saham. Sampel yang digunakan dalam penelitian ini adalah perusahaan makanan dan minuman yang terdaftar di Bursa Efek Indonesia selama periode 2016-2018. Metode regresi linier berganda digunakan untuk menganalisis pengaruh DER, CAR, dan NPM terhadap Harga Saham. Hasil penelitian menunjukkan bahwa DER dan CAR tidak berpengaruh signifikan terhadap Harga Saham. NPM berpengaruh signifikan terhadap Harga Saham.
\end{abstract}

Kata Kunci: Struktur Modal, Likuiditas, Profitabilitas, Harga Saham 


\section{PENDAHULUAN}

Pasar modal adalah sarana yang paling efektif bagi para investor dalam menanamkan modalnya agar dapat memperoleh keuntungan. Pasar Modal bertindak sebagai penghubung antara para investor dengan perusahaan ataupun institusi pemerintah melalui perdagangan instrumen melalui jangka panjang seperti obligasi, saham, dan lainnya. Setiap perusahaan yang berstatus go public dapat memperoleh modal dan melakukan perdagangan efek di pasar modal atau bursa efek, termasuk di dalamnya adalah perusahaan - perusahaan yang bergerak di bidang industri manufaktur. Saham di Industri manufaktur merupakan lahan yang strategis bagi investor untuk mengoptimalkan fungsi utilitas, sehingga dapat berinvestasi pada sektor ini.

Saham saat ini menjadi produk investasi populer dikalangan investor. Saham yang diminati investor adalah saham yang mempunyaai nilai jual tinggi karena harga saham merpakan faktor yang sangat penting untuk diperhatikan dan indikator digunakan untuk mengukur kesejahteraan pemegang saham adalah harga saham. Hartono (2016) menyatakan nilai perusahaan ditunjukkan dengan harga saham dan sebagai pengukur efektivitas perusahaan. Semakin tinggi harga saham, maka semakin tinggi nilai perusahaan tersebut dan begitu pula sebaliknya. Saham yang rendah dapat diartikan bahwa kinerja perusahaan tidak maksimal. Namun berinvestasi saham di pasar modal juga dipenuhi dengan unsur ketidakpastian atau risiko, ini dikarena investor tidak tahu dengan pasti hasil yang akan diperolehnya dari investasi yang dilakukannya. Informasi spesifik keuangan perusahaan merupakan salah satu faktor intern perusahaan yang penting yang dapat mempengaruhi investor untuk berinvestasi. Informasi termasuk dalam faktor risiko yang tidak dapat didifersifikasi (systematic risk). Informasi ini dapat dilihat dilaporan keuangan.

Laporan keuangan adalah catatan informasi keuangan suatu perusahaan pada suatu periode akuntansi yang dapat digunakan untuk menggambarkan kinerja perusahaan tersebut. Kinerja keuangan merupakan bagian yang sangat penting bagi suatu organisasi. Menurut Ikatan Akuntansi Indonesia (IAI) (2012) kinerja keuangan adalah keefektifan manajemen perusahaan dalam mefungsikan dan memberdayakan segala unsur yang ada di perusahaan, yang berarti juga semakin tinggi citra perusahaan di mata pihak luar. Didalam kinerja keuangan dapat dilihat keefektifan manajemen perusahaam dalam menfungsikan sumber daya yang ada dalam perusahaan. Untuk menilai kinerja keuangan perusahan biasnya digunakan alat analisis rasio keuangan seperti rasio stuktur modal, rasio likuiditas, rasio solvabilitas, rasio profitabilitas dan lain. Didalam penelitian ini peneliti hanya akan menggunakan rasio stuktur modal, rasio likuiditas, dan rasio profitabilitas sebagai diterminan kinerja perusahaan.

Struktur Modal merupakan komponen yang penting bagi perusahaan karena baik burukny struktur modal akan mempunyai dampak langsung terhadap posisi finansial perusahaan, yang pada akhirnya akan berpengaruh terhadap harga saha.

Likuiditas merupakan rasio keuangan perusahaan yang menggambarkan kemampuan perusahaan dalam membayar serta memenuhi kewajiban finansialnya dengan segera atau sebelum jatuh tempo (Suharti \& Tannia, 2020). Rasio ini 
berguna untuk mengetahui seberapa besar aset likuid yang bisa diubah menjadi kas untuk membayar tagihan yang tak terduga. Jika perusahaan tidak bisa membayar tagihan tersebut maka perusahaan tersebut terancam mengalami kebangkrutan. Likuiditas perusahaan dapat diukur dengan menggunakan CR (Current Rasio) atau rasio lancar yaitu rasio yang mengukur seberapa jauh aktiva lancar suatu peusahaaan dalam memenuhi kewajibannya (Amanah, 2014).

Profitabilitas merupakan rasio keuangan yang mencerminkan kemampuan suatu perusahaan dalam memperoleh laba atau dengan kata lain ukuran efektivitas pengelolaan manajemen perusahaan (Suryani \& Hamzah, 2019). Kemampuan perusahaan dalam memperoleh laba dapat diukur melalui modal sendiri hingga dari seluruh dana yang diinvestasikan ke dalam perusahaan (Wiagustini, 2014). Profitabilitas mampu mengukur sejauh mana kemampuan suatu perusahaan dalam memperoleh laba. Salah satu faktor utama mengukur tingkat efektifitas dan efisiensi perusahaan dengan seluruh dana dan sumber daya perusahaan adalah laba.

\section{METODE PENELITIAN \\ Populasi dan Sampel}

Populasi dalam penelitian ini adalah semua perusahaan Sektor Industri Barang Konsumsi yang terdaftar di Bursa Efek Indonesia. Sampel dalam penelitian ini adalah perusahann Sektor Industri Barang Konsumsi sub sektor makanan dan minuman yang terdaftar di Bursa Efek Indonesia yang mempublikasikan laporan keuangannya dari Tahun 20162017-2018. Jumlah sampel 20 perusahaan.

\section{Metode Analisis Data}

1. Analisis Diskriptif. Analisis Deskriptif adalah analisis yang dilakukan untuk menilai karakteristik dari sebuah data. Statistik deskriptif adalah statistik yang digunakan dengan cara mendeskripsikan atau menggambarkan data yang telah terkumpul tanpa bermaksud menyimpulkan data tersebut.

2. Uji Asumsi Klasik. Uji Asumsi klasik adalah analisis yang dilakukan untuk menilai apakah di dalam sebuah model regresi linear Ordinary Least Square (OLS) terdapat masalah-masalah asumsi klasik. Model regresi yang digunakan untuk membuat hubungan antara variabel terikat dengan variabel bebas disebut model regresi linier berganda. Syarat sebelum menggunakan regresi linier berganda adalah terpenuhinya uji asumsi klasik. Uji asumsi klasik meliputi: Uji Normalitas, Uji Multikolinearitas, Uji Heteroskedastisitas, dan Uji Autokorelasi

3. Analisis Regresi Linier Beranda. Analisis regresi linier berganda adalah hubungan secara linear antara dua atau lebih variabel independen dengan variabel dependen.

4. Koefesien Diterminansi (R). Koefisien determinsi (R2) mengukur seberapa jauh kemampuan model dalam menjelaskan variabel terikat

5. Uji Hipotesa

a. Uji Parsial (Uji t). Uji statistik t pada dasarnya menunjukkan seberapa jauh pengaruh satu variable penjelas atau independen secara individual dalam menerangkan variasi variable depended. Pengujian 
dilakukan dengan menggunakan nilai signifikasi level 5\%.

b. Uji Simultan (Uji F). Uji statistik $F$ pada dasarnya meunjukkan apakah semua variabel independen atau bebas yang dimasukkan dalam model mempunyai pengaruh secara bersama-sama terhadap variabel dependen atau terikat. Pengujian dilakukan menggunakan nilai signifikan level 5\%.

\section{HASIL DAN PEMBAHASAN Deskriftif Statistik}

Tabel 1. Statistik Deskriptif Variabel

\section{Descriptive Statistics}

\begin{tabular}{lrrr}
\hline & Mean & Std. Deviation & \multicolumn{1}{c}{$\mathrm{N}$} \\
\hline Harga Saham & 2324,53 & 2554,518 & 60 \\
\hline Struktur Modal &, 8387 &, 54498 & 60 \\
\hline Likuiditas & 1,8113 & 1,39050 & 60 \\
\hline Profitabilitas & 6,8053 & 5,73658 & 60 \\
\hline
\end{tabular}

Sumber: Data SPSS diolah, 2020

\section{Uji Asumsi Klasik}

\section{Uji Normalitas}

Grafik normal $P-P$ plot dapat dilihat bahwa titik-titik dalam grafik menyebar disekitar garis diagonal dan mengikuti arah garis diagonal. Analisis grafik histogram dan normal probability plot data dalam penelitian menunjukkan bahwa data terdistribusi normal

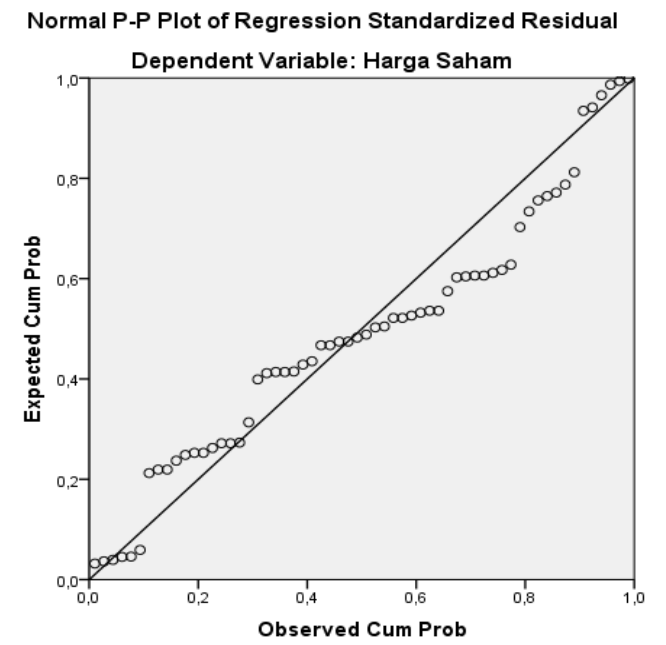

Gambar 1. Grafik P-P Plot

Sumber: Data SPSS Diolah, 2020
Uji Multikolinearitas

Tabel 2 Hasil Uji Multikolinearitas

Coefficients $^{\mathrm{a}}$

\begin{tabular}{|c|c|c|c|}
\hline \multirow[b]{2}{*}{ Model } & & \multicolumn{2}{|c|}{ Collinearity Statistics } \\
\hline & & Tolerance & VIF \\
\hline \multirow[t]{4}{*}{1} & (Constant) & & \\
\hline & Struktur Modal & ,493 & 2,029 \\
\hline & Likuiditas & ,396 & 2,528 \\
\hline & Profitabilitas & ,732 & 1,366 \\
\hline
\end{tabular}

Sumber: Data SPSS diolah, 2020

Berdasarkan hasil analisis data diketahui yaitu Struktur Modal nilai VIF sebesar $<102,029$ dan nilai Tolerance $>0,10$ yaitu sebesar 0,493 , Likuiditas nilai VIF sebesar 2,528 dan nilai Tolerance $>0,10$ yaitu sebesar 0,396 dan Profitabilitas nilai VIF sebesar 1,366 dan nilai Tolerance $>$ 0,10 yaitu sebesar 0,732. Hal ini menunjukkan bahwa tidak terjadi multikolinearitas atau tidak terjadi korelasi antar variabel bebas.

\section{Uji Heteroskedastisitas}

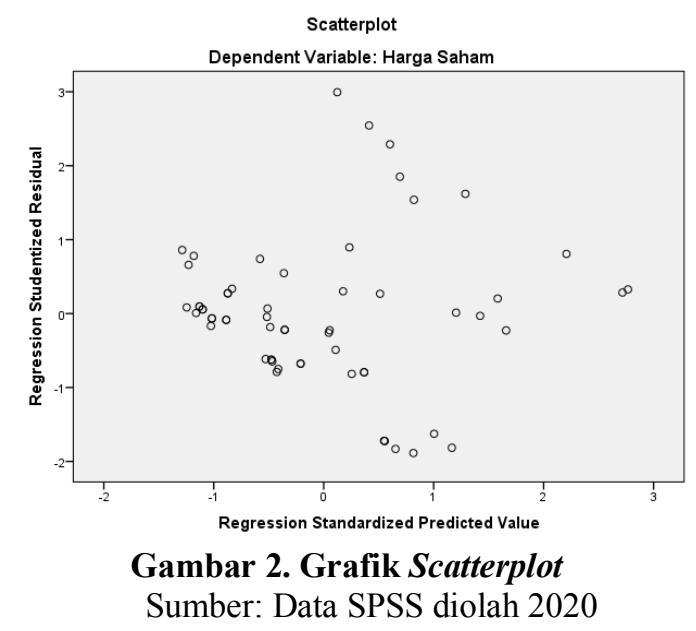

Berdasarkan grafik scatterplot tersebut terlihat bahwa titik-titik menyebar secara acak serta tersebar baik di atas maupun di bawah angka 0 pada sumbu Y, dengan demikian dapat disimpulkan bahwa tidak terjadi heteroskedastisitas pada model regresi. 


\section{Uji Autokorelasi}

Tabel 3. Hasil Uji Autokerelasi

\begin{tabular}{ll}
\hline \multicolumn{3}{c}{ Model } & Durbin-Watson \\
\hline 1 &, 960 \\
\hline a. & Predictors: (Constant), Struktur Modal, Likuiditas \\
& ,Profitabilitas \\
b. $\quad$ Dependent Variable: Harga Saham \\
Sumber: Data SPSS diolah, 2020
\end{tabular}

Berdasarkan hasil yang ditunjukkan pada tabel diatas diketahui bahwa nilai Durbin Watson hasil pengujian berada diantara $-2<, 960<$ +2 sehingga disimpulkan tidak terjadi autokorelasi pada model regresi yang terbentuk.

\section{Analsis Regresi Linier Berganda}

Tabel 4. Hasil Regresi Linier Berganda

\begin{tabular}{|c|c|c|c|c|}
\hline \multirow{2}{*}{\multicolumn{2}{|c|}{ Model }} & $\begin{array}{l}\text { Standardized } \\
\text { Coefficients }\end{array}$ & \multirow{2}{*}{$\mathrm{t}$} & \multirow[b]{2}{*}{ Sig. } \\
\hline & & Beta & & \\
\hline 1 & (Constant) & & 2,117 &, 039 \\
\hline & Struktur Modal &,- 166 & $-1,263$ &, 212 \\
\hline & Likuiditas &,- 428 & $-2,916$ &, 005 \\
\hline & Profitabilitas &, 837 & 7,758 &, 000 \\
\hline
\end{tabular}

Sumber: Data Diolah, 2020

Variabel terikat pada regresi ini adalah Harga Saham sedangkan variabel bebasnya adalah Struktur Modal, Likuiditas dan Profitabilitas. Model regresi berdasarkan hasil analisis di atas adalah:

$Y=-0,166 X 1+-0,428 \times 2+0,837 X 3+e$

\section{Koefesien Diterminansi (R)}

Tabel 5 Koefesien Diterminansi (R)

\begin{tabular}{|c|c|c|c|c|}
\hline \multirow[b]{2}{*}{ Model } & \multicolumn{4}{|c|}{ Adjusted } \\
\hline & $\mathrm{R}$ & $\begin{array}{c}\mathrm{R} \\
\text { Square }\end{array}$ & $\begin{array}{c}\mathrm{R} \\
\text { Square }\end{array}$ & $\begin{array}{l}\text { Std. Error of } \\
\text { the Estimate }\end{array}$ \\
\hline 1 &, $723^{a}$ &, 523 & ,498 & 1810,732 \\
\hline $\begin{array}{l}\text { a. Predict } \\
\text { b. Dep } \\
\text { Sumber: }\end{array}$ & $\begin{array}{l}\text { s: (Con } \\
\text { nden } \\
\text { ata S }\end{array}$ & $\begin{array}{l}\operatorname{tant} \text {, Profita } \\
\text { Variabl } \\
\text { SS diolah }\end{array}$ & $\begin{array}{l}\text { litas, Struk } \\
\text { Harga } \\
2020\end{array}$ & $\begin{array}{l}\text { ur Modal, Likuid } \\
\text { Saham }\end{array}$ \\
\hline
\end{tabular}

Berdasarkan analisis yang telah dilakukan diperoleh nilai adjusted $\mathrm{R}$ Square sebesar 0,523 atau 52,3\%. Artinya, besarnya pengaruh variable
Struktir Modal,Likuiditas dan Profitabilitas terhadap Harga Saham adalah sebesar 52,3\%. Sedangkan pengaruh sisanya yang sebesar $47,7 \%$ dijelaskan oleh variabel lain di luar persamaan regresi atau yang tidak diteliti dalam penelitian ini.

\section{Uji Hipotesis \\ Uji Parsial (Uji t)}

Tabel 9. Hasil Uji t

\begin{tabular}{llcll}
\hline $\begin{array}{c}\text { Variabel } \\
\text { Bebas }\end{array}$ & $\begin{array}{c}\mathbf{t} \\
\text { Hitung }\end{array}$ & $\begin{array}{c}\text { Sig. } \\
\mathbf{t}\end{array}$ & $\begin{array}{c}\mathbf{t} \\
\text { Tabel }\end{array}$ & Keterangan \\
\hline Struktur & $-1,263$ &, 212 & 1,673 & Tidak \\
Modal & $-2,916$ &, 005 & 1,673 & Signifikan \\
Likuiditas & 7,758 &, 000 & 1,673 & Tidak \\
Profitbilitas & & & & Signifikan \\
& & & & Signifikan \\
\hline
\end{tabular}

Sumber: Data SPSS diolah, 2020

\section{Pada Hipotesis Pertama}

pengujian Struktur Modal Terhadap Harga saham. Hasil pengujian hipotesis variabel Struktur Modal diperoleh $t$ hitung sebesar -1,263 dengan nilai signifikansi sebesar 0,212. Nilai statistik uji t hitung tersebut lebih kecil daripada $t$ tabel $(-1,263<1,673)$ atau nilai signifikansi lebih besar dari $\alpha=$ 0,05 maka disimpulkan variabel Struktur Modal tidak berpengaruh signifikan terhadap variabel Harga Saham.

Struktur modal tidah hanya membahas tentang persentase modal dan utang perusahaan. Struktur modal penting karena struktur modal bisa mempengaruhi kondisi keuangan perusahaan. Bisa mempengaruhi harga saham perusahaan. Bahkan kelangsungan hidup perusahaan bisa diprediksi. Dugaan bahwa Struktur Modal berpengaruh terhadap harga saham tidak sesuai dalam penelitian ini.

Penelitian ini mendukung penelitian yang dilkaukan oleh Hamidi (2019) yaitu Pengaruh Capital Adequacy Ratio (CAR) dan Return On Asset (ROA) Terhadap Harga Saham 
Pada Perusahan Perbankan Yang Terdaftar Di Bursa Efek Indonesia (BEI), dimana hasil penelitian menyatakan bahwa CAR tidak berpengaruh terhadap Harga Saham yang terdaftar di Bursa Efek Indonesia.

Meningkat dan menurunya Struktur Modal tidak mempengaruhi harga saham. Dalam hal ini investor tidak mempertimbangkan Struktur Modal sebagai dasar pengambilan keputusan untuk melakukan investasi dalam saham pada perusahaan.

Pada Hipotesis kedua pengujian terhadap variabel Likiuiditas terhadap Harga Saham. Hasil yang diperoleh $\mathrm{t}$ hitung sebesar -2,916 dengan nilai signifikansi sebesar 0,005. Nilai statistik uji t hitung tersebut lebih kecil daripada $t$ tabel $(-2,916<1,673)$ atau nilai signifikansi lebih besar dari $\alpha=$ 0,05 maka disimpulkan variable Likiuiditas tidak berpengaruh signifikan terhadap variabel Harga Saham.

Rasio Likuiditas Perusahaan merupakan rasio yang mengukur tingkat kemampuan perusahaan dalam memenuhi kewajiban jangka pendek yang telah jatuh tempo. Salah satu indikator digunakan Debt to Equity Ratio yang dapat mengukur kemampuan perusahaan membayar kewajiban. Semakin besar likuiditas yang dimilki perusahaan dapat meningkatkan harga saham karena menunjukan besarnya kemampuan perusahaan dalam memenuhi kebutuhan operasionalnya terutama modal kerja yang sangat penting untuk menjaga kinerja perusahaan. Hal ini dapat memberikan keyakinan kepada investor untuk memilki saham perusahaan tersebut. Dugaan bahwa Likuiditas berpengaruh terhadap harga saham tidak sesuai dalam penelitian ini.

Penelitian ini mendukung penelitian yang pernah dilakukan oleh Muksal (2017) Pengaruh Debt Equity
Ratio (DER) Terhadap Harga Saham Syariah (Studi Pada Pasar Sekunder Jakarta Islamic Index (JII), hasil pengujian menunjukkan secara parsial variabel variabel Debt to Equity Ratio (DER) tidak berpengaruh terhadap perubahan Harga Saham. Dengan meningkatnya DER tidak diikuti dengan meningkatnya harga saham perusahaan yang terdaftar di Bursa Efek Indonesia

Meningkat dan menurunya Likuiditas yang di proyeksi dengan DER tidak mempengaruhi harga saham. Dalam hal ini investor tidak mempertimbangkan likuiditas sebagai dasar pengambilan keputusan untuk melakukan investasi dalam saham pada perusahaan.

Pada Hipotesis ketiga pengujian Pada variabel Profitabilitas terhadap Harga Saham. Hasil yang diperoleh $t$ hitung sebesar 7,758 dengan nilai signifikansi sebesar 0,000 . Nilai statistik uji thitung tersebut lebih besar daripadattabel $(7,758>1,673)$ atau nilai signifikansi lebih kecil dari $\alpha=0,05$ maka disimpulkan variabel Profitabilitas secara parsial berpengaruh signifikan positif terhadap variabel Harga Saham.

Rasio Prifitabilitas mengukur efektivitas manajemen secara keseluruhan yang ditujukan oleh besar kecilnya tingkat keuntungan yang diperoleh dalam hubungannya dengan penjulan maupun investasi. Semakin baik rasio profitabilitas maka semakin baik menggambarkan kemampuan tingginya perolehan keutungan perusahaan (Irham, 2012).

Meningkatnya profitabilitas perusahaan harga saham juga cendrung akan naik, sedangkan jika laba menurun harga saham ikut menurun. Dalam hal ini investor mempertimbangkan profitabilitas sebagai dasar pengambilan keputusan melakukan investasi dalam saham pada perusahaan. 
Dugaan bahwa Prifitabilitas berpengaruh terhadap harga saham sesuai dalam penelitian ini.

Penelitian ini mendukung penelitian yang dilakukan oleh Jusmarni (2020) bahwa Net Profit Margin berpengaruh terhadap harga saham pada perusahaan Manufaktur sub sector makanan dan minuman yang terdaftar di Bursa Efek Indonesia. Hasil penelitian Net Profit Margin Berpengaruh terhadap Harga saham yang terdaftar di Bursa Efek Indonesia

\section{Uji Simultan (Uji F)}

Tabel 8. Hasil Uji F

\begin{tabular}{llcc}
\hline Model & F & Sig. \\
\hline 1 & Regression & 20,475 &, $000^{\mathrm{b}}$ \\
\cline { 2 - 3 } & Residual & \\
\cline { 2 - 2 } & & \\
\hline Total & & \\
\hline Sumber: Data SPSS diolah, 2020 &
\end{tabular}

Berdasarkan hasil perhitungan pada tabel 8 , diperoleh $\mathrm{F}$ hitung sebesar $20,475$ (Sig $F=0,000)$. F tabel pada taraf nyata $5 \%$ dengan derajat bebas 3 dan 56 sebesar 2,769. Karena F hitung $>$ F tabel $(20,475>2,769)$ dan Sig F $<5 \%$ $(0,000<0,05)$ maka Ho ditolak yang berarti bahwa secara bersama-sama variabel, Struktur Modal, Likuiditas dan Profitabilitas mempunyai pengaruh yang signifikan terhadap variabel Harga Saham.

Hipotesis ke empat mengajuji pengaruh Struktur modal, likuiditas dan profitabilitas perusahan secara bersamabersama terhadap harga saham. Hasilnya secara simultan Struktur modal, likuiditas dan profitabilat memilki pengaruh terhadap harga saham. Penelitian ini mendukung penelitian yang telah dilakukan oleh Hutapea \& Saerang (2017) yaitu Pengaruh Return On Asset, Net Profit Margin, Debt to Equity Ratio, dan Total Asset Turnover Terhadap Harga Saham Industri Otomotif dan Komponennya yang Tedaftar Di Bursa Efek Indonesia, dimana Debt to Equity Ratio dan Net Profit Margin secara bersama-sama berpengaruh terhadap harga saham.

Salah satu faktor yang membuat suatu perusahan memiliki daya saing dalam jangka panjang karena factor kuatnya struktur modal yang dimilikinya (Irham, 2012). Struktur modal adalah memadukan sumber dana permanen yang yang selanjutnya digunakan perusahaan dengan cara yang diharapkan akan mampu memaksimalkan nilai perusahaan. Turunnya Struktur modal diduga bisa menurunkan nilai perusahaan. Turunnya nilai perusahaan bisa mempengaruhi pada turunnya nilai saham perusahaan.

Likuiditas merupakan salah satu faktor yang yang dapat mendorong terjadi perubahan harga saham Rasio likuiditas menunjukan sejauh mana aktiva lancar mampu memenuhi kewajiban pendeknya tepat waktu (Irham, 2012). Apabila perusahaan diyakini mampu untuk melunasi kewajiban kewajiban jangka pendeknya maka perusahaan dalam kondisi baik dan dapat meningkatkan harga saham.

Rasio profitabilitas mengukur efektivitas manajemen secara keseluruhan yang ditukan oleh besar kecilnya tingkat keuntangan yang diperoleh dalam hubungannya dengan penjualan maupun investasi (Irham, 2012). semakin tinggi profitabilitas perusahaan maka akan membuat harga saham juga terpengaruh. Dengan meningkatnya profitabilitas maka harga saham cenderung naik, sedangkan ketika laba menurun maka harga saham ikut juga turun.

Dalam penelitian ini profitabilitas di proksikan dengan NPM (net profit margin). Margin laba besih sama dengan laba bersih dibagi dengan penjualan besih. Ini menunjukan kestabilan kesatuan untuk menghasilkan 
perolehan pada tingkat penjulan khusus. Dengan memeriksa margin laba sebuah perusahaan pada tahun-tahun sebelumnya kita dapat menilai efesiensi operasi penetapan harga status persaingan perusahaan dengan perusahaan lain dalam industry tersebut. Margin laba yang tinggi lebih disukai karena menunjukan bahwa perusahaan mendapat hasil yang baik yang melebihi harga pokok penjualan.

Penelitian ini mendukung penelitian yang pernah dilakukan oleh Putri (2017), yang meneliti Pengaruh ROA, CAR, NPM dan LDR dan Terhadap Harga Saham Bank Umum. Hasil Penelitian secara simultan ROA, CAR, NPM dan LDR dan Terhadap Harga Saham.

\section{PENUTUP \\ Kesimpulan}

Penelitian ini bertujuan untuk mengetahui pengaruh struktur modal, likuiditas dan profitabilitas secara simultan dan parsial terhadap harga saham pada perusahaan makanan dan minuman yang terdaftar di Bursa Efek Indonesia periode 2016 - 2018.

Berdasarkan hasil analisis dan pengujian hipotesis, dapat disimpulkan sebagai berikut:

1. Struktur modal (X1) diproyeksikan dengan DER, Likuiditas (X2) diproyesikan dengan CAR, dan Profitabilitas (X3) yang diproyeksikan NPM berpengaruh secara simultan dan signifikan terhadap Harga Saham (Y). Besarnya pengaruh DER (X1), CAR (X2), dan NPM (X3) terhadap Harga Saham (Y) adalah sebesar $52,3 \%$. Sisanya sebesar $47,7 \%$ dijelaskan oleh variabel lain di luar yang tidak diteliti dalam penelitian ini.
2. Secara parsial Struktur modal (X1) diproyeksikan dengan DER, Likuiditas (X2) diproyesikan dengan CAR tidak berpengaruh signifikan terhadap Harga Saham (Y).

3. Secara parsial Profitabilitas (X3) yang diproyeksikan NPM secara parsial berpengaruh signifikan terhadap Harga Saham (Y).

\section{Saran}

Adapun saran dalam penelitian ini adalah : Bagi Investor atau Calon Investor saham lebih teliti lagi dalam mempertimbngkan kondisi perusahaan untuk berinvestasi dengan memperhatikan tingkat struktur modal, likuiditas dan profitabilitas perusahaan sebelum pengambilan keputusan untuk menanamkan modal. Selanjutnya bagi peneliti selanjutnya lebih baik menambahkan variable lain yang berhubungan dengan harga yang belum ada dalam penelitian ini dan menambah periode tahun penelitian.

\section{DAFTAR PUSTAKA}

Amanah, R. (2014). Pengaruh rasio likuiditas dan rasio profitabilitas terhadap harga saham (Studi pada perusahaan Indeks LQ45 periode 2008-2012). Jurnal Administrasi Bisnis, 12(1).

Hartono, J. (2016). Teori Portofolio dan Analisis Investasi (10th ed.). Yogyakarta: BPFE.

Hamidi, H. (2019). Pengaruh Capital Adequacy Ratio (Car) Dan Return On Asset (Roa) Terhadap Harga Saham Pada Perusahaan Perbankan Yang Terdaftar Di Bursa Efek Indonesia (BEI). Jurnal Dimensi, 8(3), 552-572. 
Hutapea, A. W., \& Saerang, I. S. (2017). Pengaruh Return On Assets, Net Profit Margin, Debt To Equity Ratio, Dan Total Assets Turnover Terhadap Harga Saham Industri Otomotif Dan Komponen Yang Terdaftar Di Bursa Efek Indonesia. Jurnal EMBA: Jurnal Riset Ekonomi, Manajemen, Bisnis dan Akuntansi, 5(2).

Irham, F. (2012). Pengantar Pasar Modal. Bandung: Alfabeta

Jusmarni. (2020). Pengaruh Dividen Per Share dan Net Profit Margin Terhadap Harga Saham yang Terdaftar di Bursa Efek Indonesia. Jurnal Akuntansi Kompetif. 3(2): 34-79.

Muksal, M.,E.,I (2017). Pengaruh Debt Equity Ratio (DER) Terhadap Harga Saham Syariah (Studi Pada Pasar Sekunder Jakarta Islamic Index (JII)).

Putri, D. A. (2017). Pengaruh ROA, CAR, NPM, dan LDR terhadap
Harga Saham Bank

Umum. Jurnal Ilmu dan Riset Manajemen (JIRM), 6(4).

Suharti, \& Tannia, Y. (2020). Analisis Pengaruh Debt to Equity Ratio, Debt to Asset Ratio, Price Earning Ratio dan Price to Book Value Terhadap Harga Saham Pada Perusahaan Sektor Pertanian. INVEST : Jurnal Inovasi Bisnis Dan Akuntansi, 1(1), 13-26.

Suryani, F., \& Hamzah, Z. (2019). Pengaruh Rasio Lancar, Rasio Cepat, Rasio Utang terhadap Ekuitas terhadap Laba pada Perusahaan Industri Konsumsi. Management Studies and Entrepreneurship Journal (MSEJ), 1(1), 25-37.

Wiagustini, N., L., P. (2014). Manajemen Keuangan (1st ed.). Denpasar: Udayana University Press. 